\title{
Efficiency of Crude Extract of Ocimum sanctum, Ocimum gratissimum and Ocimum basilicum Leaves against Bacterial Pathogens
}

\author{
Veena Krishnamurthy ${ }^{1}$, S.C. Chandrashekar ${ }^{1 *}$, M. Sudeep Kumar ${ }^{1}$ and Dhruva Sagar ${ }^{2}$ \\ ${ }^{1}$ Department of Microbiology, Sri Siddhartha Medical College, Tumkur, India \\ ${ }^{2}$ Sri Siddaganga college of Pharmacy, Tumkur, India \\ *Corresponding author
}

\begin{tabular}{|l|}
\hline Ke y w or d s \\
Antimicrobial, \\
$\begin{array}{l}\text { Efficacy, Disc- } \\
\text { diffusion, Ocimum }\end{array}$ \\
\hline Article Info \\
\hline $\begin{array}{l}\text { Accepted: } \\
20 \text { March } 2018 \\
\text { Available Online: } \\
\text { 10 April 2018 }\end{array}$ \\
\hline
\end{tabular}

A B S T R A C T

Antibiotic resistance and the clinical efficacy of existing antibiotics have become a major cause of concern. The indiscriminate use of commercial antimicrobial drugs to treat infectious diseases has also sometimes been associated with negative effects on the host such as hypersensitivity, immune response and allergic reactions. Hence there is need to develop alternative antimicrobial drugs to treat infectious disease from various sources including plants. Ocimum have shown strong antioxidant and antimicrobial activity. Ocimum plant is an annual and perennial herbal plant. The aim of the present study was to investigate the antimicrobial activity of leaf extract of different species of Ocimum to different bacterial agents by disc diffusion methods. Strains of Escherichia coli, Bacillus subtilis, Staphylococcus aureus, Shigella dysentriae and Salmonella typhimurium were selected to study the antimicrobial activity of leaf extract of Ocimum species. The antimicrobial activity was test by Kriby Bauer disc diffusion method against three different concentrations viz., $250 \mu \mathrm{g}, 500 \mu \mathrm{g}$ and $1000 \mu \mathrm{g}$. The antimicrobial activity was maximum at the disc concentration of $1000 \mu \mathrm{g} / \mathrm{ml}$, followed by $500 \mu \mathrm{g} / \mathrm{ml}$ and $250 \mu \mathrm{g} / \mathrm{ml}$. the zone of inhibition was the highest $1.5 \mathrm{~cm}$ for Escherichia coli, $1.4 \mathrm{~cm}$ for Shigella dysentriae and $1.3 \mathrm{~cm}$ for Salmonella typhimurium, and $1.2 \mathrm{~cm}$ for Bacillus subtilis and Staphylococcus aureus. The antimicrobial activity of plant extract in our study was better for Escherichia coli than other bacteria. The results of the present study support the medicinal use of plant for treatment of various ailments and determination of appropriate concentration for therapy can be useful.

\section{Introduction}

Infectious diseases have become the leading cause of death world-wide, Antibiotic resistance and the clinical efficacy of existing antibiotics has become a major cause of concern. Increase in the development of multidrug resistance (MDR) strains has been the cause of raise in the number of untreatable bacterial infections (Singh et al., 2013).

MDR among Staphylococcus sps, Pseudomonas sps, Escherichia coli and many other pathogenic bacteria have been reported worldwide. $\beta$ lactamase enzyme produced by these organisms breakdown the $\beta$-lactam ring leading to resistance to penicillin and 
penicillin group of drugs. The indiscriminate use of commercial antimicrobial drugs to treat infectious diseases has also sometimes been associated with negative effects on the host such as hypersensitivity, immune response, and allergic reactions. Hence there is need to develop alternative antimicrobial drugs to treat infectious disease from various sources including plants (Naik et al., 2015).

Plants are the richest source of traditional system of medicine, modern medicine, nutraceuticals, food supplements, folk medicine, pharmaceutical intermediates and chemical entities for synthetic drugs. Products of medicinal plants have been used for purposes of food preservation, pharmaceuticals, alternative medicine and natural therapies. These products are produced naturally and are biodegradable easily and are environmentally acceptable. Natural antioxidants, antibacterial, cytotoxic, antiviral, fungicidal activity has gained popularity in recent years (Prasad et al., 2012; Kaya et al., 2008).

Many herbs species, especially of the family Laminaceae, Ocimum have shown strong antioxidant and antimicrobial activity. Ocimum plant is an annual and perennial herbal plant.

Ocimum sanctum, $O$. gratissimum, $O$. canum, O. camphora, O. minimum, O. tenuiform and $O$. micranthun are some of the important species found worldwide (Dev et al., 2011; Garg and Sardana, 2016). Holy Basil as it is commonly called is used as a remedy for a lot of ailments such as fever, common cold, cough, sore throat, stress, mouth infections, insect bites, skin disorders, headaches, eye disorders, teeth disorders, liver support, lung and bronchial support, radiation protection, immunity tune up, anti-inflammatory action etc. (Gupta et al., 2013).
The aim of the present study was to investigate the antimicrobial activity of leaf extract of different species of Ocimum to different bacterial agents.

\section{Materials and Methods}

Fresh leaves of Ocimum sanctum, Ocimum gratissimum and Ocimum basicilum were obtained from horticulture garden, Nammachulemae, Tumkur. The species were identified with the help of department of Pharmacognosy, Sri Siddaganga College of Pharmacy, Tumkur.

\section{Bacterial cultures used}

Organisms isolated from clinical specimens were first identified by standard biochemical tests and preserved by refrigeration. Bacterial agents used were Staphylococcus aureus, Bacillus subtilis, Escherichia coli, Proteus mirabilis, Shigella dysentriae, Salmonella typhimurium.

Standard strains such as Staphylococcus aureus ATCC 25923 and Escherichia coli ATCC 25922 were also included in the study.

\section{Preparation of plant extract}

The leaves of $O$. sanctum, $O$. gratissimum and $O$. basilicum were washed in tap water, shade dried at room temperature and powdered in an electric grinder or with help or mortar and pestle. The extract was prepared by the method of Alede and Irobi with minor modifications.

\section{Cold water extract}

$5 \mathrm{~g}$ of shade tried leaves of Ocimum sanctum, Ocimum gratissimum and Ocimum basilicum were homogenised with mortar and pestle.in $5 \mathrm{ml}$ distilled water $(1 / 1 \mathrm{w} / \mathrm{v})$ and filtered through a double layered cheese cloth. Filtrate was collected and evaporated under room 
temperature, $5 \mathrm{mg}$ of the collected residue was dissolved in 5\% dimethylsulphoxide (DMSO) and considered as cold water extract (Alede and Irobi, 1993).

\section{Antimicrobial activity}

The antimicrobial activity of compounds is tested by several methods like disc diffusion and agar dilution. In the present study we have used the disc diffusion method to check the antimicrobial activity of different species of Ocimum. The disc diffusion method widely used is the Kirby Bauer method (Bauer et al., 1966).

\section{Preparation of inoculum}

The organisms to be tested were inoculated into peptone water and incubated at $37^{\circ} \mathrm{C}$, bacterial suspension containing $10^{5}$ cells were calibrated using Mac Farland turbidity standard opacity tubes.

\section{Preparation of filter paper discs}

Disc of $6 \mathrm{~mm}$ diameter were prepared using Whatman No. 1 filter paper, sterilized in hot air oven and impregnated with different concentration of the leaf extract of Ocimum species. The concentrations used in the study were $250 \mu \mathrm{g}, 500 \mu \mathrm{g}$ and $1000 \mu \mathrm{g}$. Control discs were prepared using $1 \%$ DMSO.

Three different concentrations were prepared using DMSO as the solvent

$1000 \mu \mathrm{g} / \mathrm{ml}$ of the plant extract $=5 \mathrm{mg}$ leaf residue dissolved in $5 \mathrm{ml}$ of $1 \% \mathrm{DMSO}$, $500 \mu \mathrm{g} / \mathrm{ml}$ of the plant extract $=2.5 \mathrm{mg}$ leaf residue dissolved in $5 \mathrm{ml}$ of $1 \% \mathrm{DMSO}$, $250 \mu \mathrm{g} / \mathrm{ml}$ of the plant extract $=1.25 \mathrm{mg}$ leaf residue dissolved in $5 \mathrm{ml}$ of $1 \% \mathrm{DMSO}$ (Alede and Irobi, 1993).

Antimicrobial activity of Ocimum sps leaf extract
Mueller Hinton Agar plates were seeded with $5 \mathrm{ml}$ of the inoculum containing $10^{5}$ cells. The excess of the fluid was discarded and disc containing $250 \mu \mathrm{g}, 500 \mu \mathrm{g}$ and $1000 \mu \mathrm{g}$ of the extract were placed at a distance of $15 \mathrm{~mm}$ from each other, a control disc containing $1 \%$ DMSO was also included. The plated were incubated at $37^{\circ} \mathrm{C}$. Zone size was recorded in centimetre $(\mathrm{cm})$ after overnight incubation.

\section{Results and Discussion}

Strains of Escherichia coli, Bacillus subtilis, Staphylococcus aureus, Shigella dysentriae and Salmonella typhimurium were selected to study the antimicrobial activity of leaf extract of Ocimum species.

The antimicrobial activity was test by Kriby Bauer disc diffusion method against three

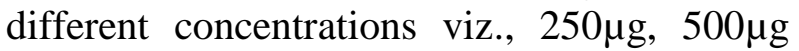
and $1000 \mu \mathrm{g}$

The inhibitory effect of three species of Ocimum against test organisms is given in table 1,2 and 3.

The antimicrobial activity of cold water extract of leaves of Ocimum species to different bacterial pathogens showed varying zones of inhibition.

The zone of inhibition for leaf extract of Ocimum gratissimum was better compared to Ocimum sanctum and Ocimum basilicum. Though the difference in the zone diameter was not very significant among the three species of Ocimum tested, the antimicrobial activity of standard strains matched to that of the test strains.

The antimicrobial activity was maximum at the disc concentration of $1000 \mu \mathrm{g} / \mathrm{ml}$, followed by $500 \mu \mathrm{g} / \mathrm{ml}$ and $250 \mu \mathrm{g} / \mathrm{ml}$. the zone of inhibition was the highest $1.5 \mathrm{~cm}$ for 
Escherichia coli, $1.4 \mathrm{~cm}$ for Shigella dysentriae and Salmonella typhimurium, 1.3 $\mathrm{cm}$ and $1.2 \mathrm{~cm}$ for Bacillus subtilis and Staphylococcus aureus respectively.

The antimicrobial activity of the leaf extract of all the three species of Ocimum was good for gram negative organisms than gram positive organisms.

The antibacterial activity against Staphylococcus aureus was maximum at the concentration of $1000 \mu \mathrm{g} / \mathrm{ml}$ and $500 \mu \mathrm{g} / \mathrm{ml}$. The zone of inhibition for leaf extract of Ocimum gratissimum and Ocimum sanctum was $1.2 \mathrm{~cm} / \mathrm{ml}$. The zone of inhibition for disc bearing concentration of $250 \mu \mathrm{g} / \mathrm{ml}$ was the least among all the three species.

The antibacterial activity of Ocimum basilicum against Shigella dysentriae was the less $0.8 \mathrm{~cm}$ for disc concentration of $1000 \mu \mathrm{g} / \mathrm{ml}$ compared to the other two species.

Table.1 Inhibitory effect of Ocimum sanctum against test organisms

\begin{tabular}{l}
$\begin{array}{r}\text { Name of the microbial } \\
\text { agent }\end{array}$ \\
\hline Staphylococcus aureus \\
\hline Bacillus subtilis \\
\hline Escherichia coli \\
\hline Proteus mirabilis \\
\hline Shigella dysentriae \\
\hline Salmonella typhimurium \\
\hline
\end{tabular}

\begin{tabular}{|c|c|c|c|}
\hline \multicolumn{4}{|c|}{ Zone of inhibition in cm } \\
\hline $0 \mu \mathrm{g} / \mathrm{ml}$ & $250 \mu \mathrm{g} / \mathrm{ml}$ & $500 \mu \mathrm{g} / \mathrm{ml}$ & $1000 \mu \mathrm{g} / \mathrm{ml}$ \\
\hline- & 0.5 & 0,8 & 1.2 \\
\hline- & 0.6 & 0.7 & 1.2 \\
\hline- & 0.8 & 1.0 & 1.4 \\
\hline- & 0.7 & 0.7 & 1.2 \\
\hline- & 0.7 & 0.9 & 1.0 \\
\hline- & 0.7 & 0.9 & 1.2 \\
\hline
\end{tabular}

Table.2 Inhibitory effect of Ocimum gratissimum against test organisms

\begin{tabular}{|c|c|c|c|c|}
\hline \multirow{2}{*}{$\begin{array}{c}\text { Name of the microbial } \\
\text { agent }\end{array}$} & \multicolumn{4}{|c|}{ Zone of inhibition in $\mathrm{cm}$} \\
\hline & $0 \mu \mathrm{g} / \mathrm{ml}$ & $250 \mu \mathrm{g} / \mathrm{ml}$ & $500 \mu \mathrm{g} / \mathrm{ml}$ & $1000 \mu \mathrm{g} / \mathrm{ml}$ \\
\hline Staphylococcus aureus & - & 0.7 & 0.9 & 1.2 \\
\hline Bacillus subtilis & - & 0.7 & 0.7 & 1.3 \\
\hline Escherichia coli & - & 0.9 & 1.1 & 1.5 \\
\hline Proteus mirabilis & - & 0.6 & 0,7 & 1.3 \\
\hline Shigella dysentriae & - & 0.8 & 0.9 & 1.4 \\
\hline Salmonella typhimurium & - & 0.8 & 1,1 & 1.4 \\
\hline
\end{tabular}

Table.3 Inhibitory effect of Ocimum basilicum against test organisms

\begin{tabular}{|l|c|c|c|c|}
\hline \multicolumn{1}{|c|}{\begin{tabular}{l} 
Name of the microbial \\
\multicolumn{1}{c|}{ agent }
\end{tabular}} & \multicolumn{4}{|c|}{ Zone of inhibition in cm } \\
\hline Staphylococcus aureus & $-250 \mu \mathrm{g} / \mathrm{ml}$ & $500 \mu \mathrm{g} / \mathrm{ml}$ & $1000 \mu \mathrm{g} / \mathrm{ml}$ \\
\hline Bacillus subtilis & - & 0.6 & 0.7 & 0.9 \\
\hline Escherichia coli & - & 0.6 & 0.8 & 1.0 \\
\hline Proteus mirabilis & - & 0.7 & 1.0 & 1.2 \\
\hline Shigella dysentriae & - & 0.5 & 0.6 & 1.0 \\
\hline Salmonella typhimurium & - & 0.7 & 0.7 & 0.8 \\
\hline
\end{tabular}


Plants are an important source of medicine. A large number of drugs are derived from plants like morphine from Papaver somniferum, atropine from Atropa belladonna etc. they are also rich source of secondary metabolites and essential oils of therapeutic importance. Among the plants known for medicinal value, Ocimum species of the family Libiatae are very important for their therapeutic potential. Essential oils extracted from Ocimum sanctum contain biologically active constituents that have insecticidal, nematocidal and fungicidal activity. The two major constituents of essential oil of Ocimum basilicum are juvocimena I and II which have been reported as potent juvenile hormone analogues. Fresh leaves of Ocimum gratissimum along with other properties also have low protein content and are rich in minerals such as phosphorus, selenium, iron and zinc.

The extraction method used was cold water extraction. Many studies have used cold water extraction of Ocimum leaves. In traditional medicine water has been used as the main solvent primarily for drug absorption but data from scientific works have better result with other solvents like methanol etc.

All parts of the plant stem, root, leaves and inflorescence have been used to study the antimicrobial activity and learn their therapeutic use (Dev et al., Shiju, 2014; Oboh and Enabulala, 2009).

Kirby disc diffusion method was employed to study the antimicrobial activity of the leaf extract. This is the most commonly used technique to determine the antimicrobial activity. The pattern of growth of an organism on the inoculated plate begins at the point distinct from the crude extract reservoir and proceeds inwards until a point is reached where the concentration of the crude extract is inhibitory to the organism (Shiju, 2014).
Among the bacterial isolates tested gram negative bacteria were more susceptible to the leaf extract than gram positive bacteria. The plant extract may attach to the surface of the microbial cell membrane disturbing its permeability, respiratory function and limiting the multiplication of the bacteria. The gramnegative bacteria have an outer phospholipid membrane that makes the cell wall permeable to the lipolytic solutes. The interaction of plant extract with the microbial cytoplasm components and nucleic acids can inhibit the respiratory chain enzymes causing inactivation of the bacterial multiplication and finally cell death. The susceptibility of plant extract to gram positive and gram negative bacteria varies in different studies (Srinivas et al., 2015; Obeidat et al., 2012)

The antimicrobial susceptibility pattern of cold water extract of leaves of Ocimum species was found to be active against all tested organisms. Many studies have used different methods of extraction using different solvents like acetone, methanol, chloroform including both hot and cold water, higher antimicrobial property was exhibited by ethanol, benzene and chloroform extract as some of the plant components are water insoluble. Cold water extract exhibit better antimicrobial activity as some of the metabolites are destroyed by different extraction methods. The antimicrobial activity extracts to different pathogenic organisms is due to the presence of tannins, essential oils. flavonoids, alkaloids and eugenol in varying proportions in these Ocimum species Phytochemicals exert their antimicrobial activity through different mechanisms tannins act by iron deprivation, hydrogen bonding or non-specific interaction with vital proteins or enzymes, alkaloids by DNA intercalator and topoisomerase inhibition (Melvingoe et al.,).

The antimicrobial activity of plant extract in our study was better for Escherichia coli than 
other bacteria. Leafy vegetables have high moisture content which support the growth of wide range of microorganisms especially Escherichia coli and Staphylococcus aureus which produce heat stable toxins, these agents act as common food poisoning bacteria, antimicrobial activity of Ocimum species can inhibit the growth of these bacteria on the vegetable in sauces and stews, thus protecting the consumer (Oboh and Enabulala, 2009).

The antimicrobial activity of leaf extract was found higher at a concentration of $1000 \mu \mathrm{g} / \mathrm{ml}$ followed by $500 \mu \mathrm{g} / \mathrm{ml}$ and $250 \mu \mathrm{g} / \mathrm{ml}$. Similar results have been obtained by other workers (Shiju, 2014). These findings indicate that extracts of Ocimum species possess antimicrobial activity and they cause lysis and eradicate bacteria by degrading bacterial cell walls. Purification of the active products from the extracted can help in discovery of new natural drugs to combat nosocomial pathogens and antibiotic resistant bacteria.

The results of the present study support the view that plant products have antimicrobial potential. The antimicrobial activity can be better in increased concentrations of the plant extract. Medicinal use of plant for treatment of various ailments and determination of appropriate concentration for therapy can be useful. Leaves of Ocimum species extracted by cold water technique possess antibacterial activity against gram positive and gramnegative bacteria. Tannins, saponin, glycosides, sterols present in these extracts have antimicrobial activity. Bio-active produces of plants can be a rich source for therapeutic use.

\section{References}

Alede PI, and Irobi ON. Antimicrobial activities of crude extracts of Acalypha wilkesinna, J Ethnopharmacol 1993; 39;
171-4 http:dx.doi.org/10.1016/03788741(93)90033-2.

Ba-Hamdan AHA, Aly MM, Bafeel SO. Antimicrobial activities and phytochemical analysis of the essential oil of Ocimum basilicum collected from Jeddah Region, Saudi Arabia, J of Microbial Res 2014; 4(2A):1-9.

Bauer AW, Kirby WM, Sherris JC, Turck M, Antibiotic susceptibility testing by a standardized single disk method. Am J ClinPathol 1966; 45:493-96.

Dev N, Das AK, Hassain MA, Rahman SMM. 2011. Chemical Composition of different extracts of Ocimum basilicum leaves. J Sci Res; 3(1):197-206.

Garg P and Sardana S. Pharmacological and therapeutic effects of Ocimum sanctum. Euro Journal of Pharmaceutical and Medical Res 2016; 3(8):637-40.

Gupta B, Kumar VN, Mallaiah S. Assessment of antimicrobial activity of various concentration of commercially available tulsi (Ocimum sanctum) powder against Streptococcus mutans. Open J Dentistry and oral Medicine 2013; 1(2):19-24.

Kaya I, Yigit N. Benli M. Antimicrobial activity of various extracts of Ocimum basilicum $L$. and observation of the inhibition effect on bacterial cells by use of scanning electron microscopy. Afr J Tradil Complement Alter Medicine 2008; 5(4):363-69.

Melvingoe M, Jayachitra J, Vijayapriya M. Pandeeswari N. Efficacy of Ocimum sanctum $\mathrm{L}$ extract for antimicrobial activity against certain pathogens.

Naik SL, Shayam P, Marx KP, Baskari. S. Antimicrobial activity and phytochemical analysis of Ocimum tenuiflorum leaf extract. Int J Pharm Tech Res 2015; 8(1):88-95.

Obeidat M, Shatnawi M, Al-alawi M, Al-Zubi E, Dmoor HA, Antimicrobial activity of crude extract of some plant leaves. Res J Microbial 2012; 7(1):59-67. 
Oboh FOJ, and Enabulala. Nutritional and Antimicrobial properties of Ocimum gratissimum leaves. J Biological Science 2009; 9(4):377-80.

Prasad MP, Jayalakshmi K, Rindhe GG. Antimicrobial activity of Ocimum species and phytochemical and antioxidant potential. Int $\mathrm{J}$ Microbial Res 2012; 4(8):302-7.

Shiju M. An Evaluation of the antimicrobial activity of various concentrations of Ocimum sanctum against various species of bacteria: an In vitro study. IJAS 2014; 3(1):33-6.

Singh AR, Bajaj VK, Sekhawath PS, Singh K. Phytochemical estimation and Antimicrobial activity of Aqueous and Methanol extracts of Ocimum sanctum L. J. Nat. Prod. Plant Resour 2013; 3(1):51-8.

Srinivas NK, Shyam P, Marx KP, Baskari S, Devi RV. Antimirobial activity and phytochemical analysis of Ocimum tenuiflorum leaf extract. IJPRIF 2015; 8(1):88-95.

\section{How to cite this article:}

Veena Krishnamurty, S.C. Chandrashekar and Sudeep Kumar, M. 2018. Efficiency of Crude Extract of Ocimum sanctum, Ocimum gratissimum and Ocimum basilicum Leaves against Bacterial Pathogens. Int.J.Curr.Microbiol.App.Sci. 7(04): 2609-2615. doi: https://doi.org/10.20546/ijcmas.2018.704.297 